\title{
Are you kidding, doc?
}

$\mathrm{M}$ edical regulatory authorities that fail to conduct criminal records checks on physicians before issuing licences to practise are either "negligent" or "ridiculously naive," patient advocates say.

They're calling on provincial-territorial governments to obligate medical licensing bodies to conduct such checks at entry to practise or relicensure and express shock that such screening isn't already the norm across Canada.

"People take it for granted that it's being done behind the scenes, that everybody has done all the checks they could do," says Sharon Shore, a patient advocate and lawyer based in Toronto, Ontario. "Given that physicians literally have our lives in their hands, to require a criminal background check really is a 'no brainer'."

But provincial medical licensing bodies remain divided as to whether the administrative costs of such screening programs outweigh their potential benefits. They also claim physicians are unlikely to lie about having a criminal record and argue that it's improbable that dishonest doctors could elude the scrutiny of regulators (www.cmaj.ca /lookup/doi/10.1503/cmaj.109-4113).

Meanwhile, regulators outside of Canada report that criminal background checks are a necessary tool for weeding out disreputable physicians and help regulators identify physicians in need of substance abuse treatment or such interventions as anger management courses (www.cmaj.ca/lookup/doi /10.1503/cmaj.109-4114).

Patient advocates in Canada charge that regulatory authorities which refuse to conduct background checks are duping patients and/or deluding themselves that physicians will necessarily self-disclose their criminal records.

"People don't self-disclose things that harm their own interests," Shore observes. "Yes, $99 \%$ of physicians or health care professionals who have nothing that they need to disclose because they have no criminal background or no

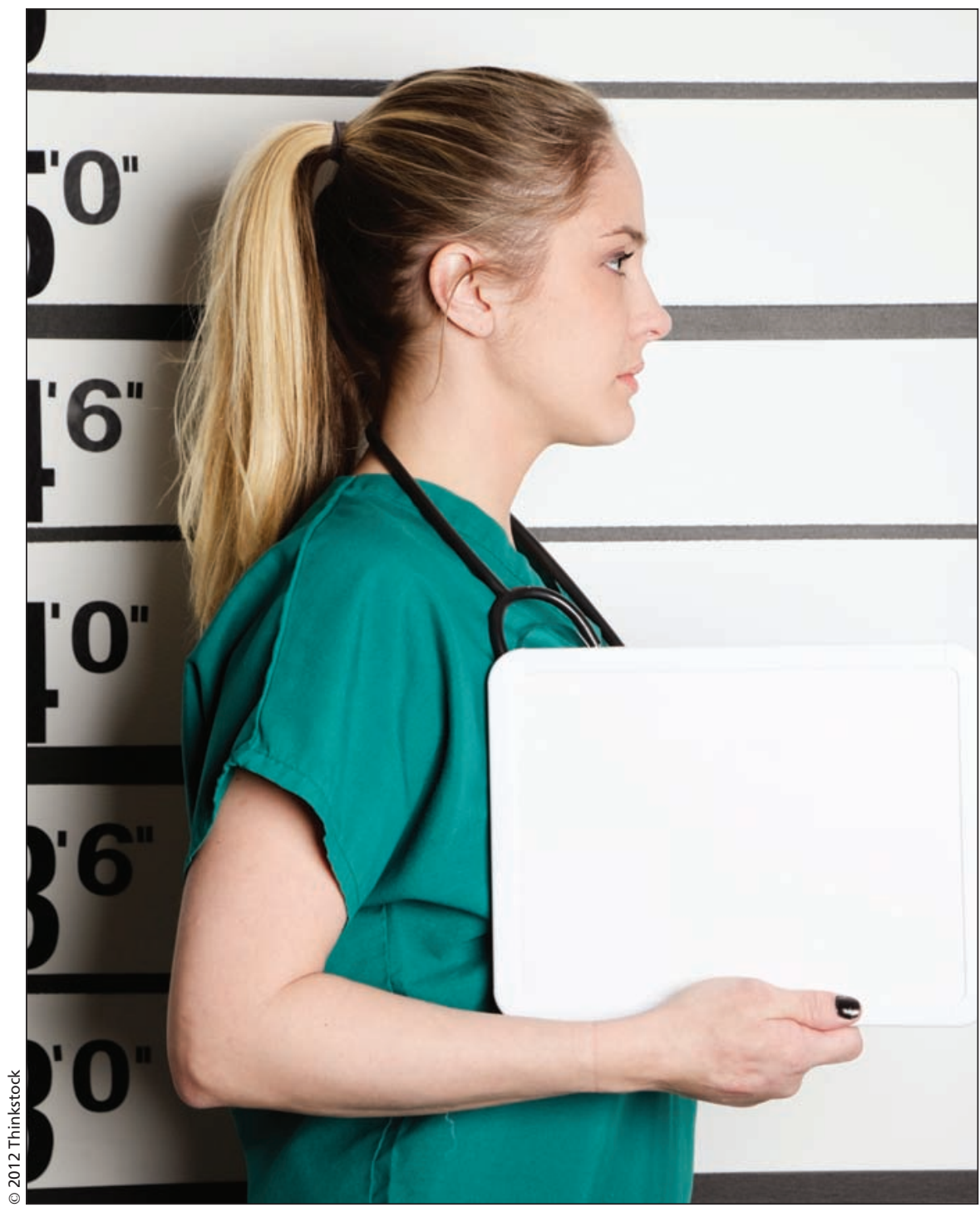

Public health advocates argue that physicians and other health professionals should be no more exempt from undergoing background checks than police officers, firefighters or any other group that has contact with vulnerable individuals.

questionable background are honest. But it's the very people [who are not honest] that you need to catch."

It once may have been enough to take physicians at their word because they were engaged in a more continuous relationship with their patients and communities, says Dr. Sholom Glouberman, founding president of the Patients' Association of Canada. But "medical practice is becoming less and less continuous and more episodic," and fewer people know anything about their doctors.

Canadian Health Coalition National Coordinator Michael McBane argues that physicians should be no more exempt from undergoing background checks than police officers, firefighters or any other group that has contact with vulnerable individuals. "I remember my children having to get police checks to do [high school] community volunteer work. So if they're doing that to 15 
and 16 year olds, how is it people with serious professional responsibilities are not subject to the same due diligence?"

Shore contends it's nothing short of regulatory negligence to ignore an easy solution to a potential problem that could have serious ramifications on patient safety and the profession's reputation. "It's one thing if you don't know about [a problem] and you find out because something bad happened and nobody had any idea. But once you know about a problem, or a potential problem or a way to resolve a problem before it happens ... how could you not take a simple step?"

Shore also rejects the proposition advanced by some provincial regulators that they shouldn't have to screen physicians because their communities are small enough that everyone knows everyone else's past. People who "run away to avoid their past run away from anybody who might have known them. They go to small towns and they go to places that are a little further out precisely because they want to hide their backgrounds."

That could have potentially serious implications for remote and Aboriginal communities in Canada's territories, where a licence to practise can be obtained without undergoing a background check, and which already face significant vulnerabilities because they're so desperate to get physicians to work in remoter environments, Glouberman argues.

McBane contends it's incumbent on governments to implement mandatory criminal checks. "What you're getting into is should the precautionary principle apply or should we deal with problems only after they emerge? I would come down on the precautionary side." - Lauren Vogel, CMAJ

CMAJ 2012. DOI:10.1503/cmaj.109-4115

Final of a three part series:

Part 1: Have you done time, doc? (www.cmaj.ca/lookup/doi/10.1503 /cmaj.109-4113).

Part 2: A check a day keeps the bad apple away

(www.cmaj.ca/lookup/doi/10.1503

/cmaj.109-4114). 